\title{
Community Structure of Sporulating Fungi on Decaying Litters of Shorea spp.
}

\author{
ISRAWATI HARAHAP ${ }^{1}$, GAYUH RAHAYU ${ }^{1}$, AND IMAN HIDAYAT ${ }^{2 *}$ \\ 'Department of Biology, Faculty of Mathematics and Natural Sciences, Kampus Dramaga, \\ Institut Pertanian Bogor, Bogor 16680. Indonesia; \\ ${ }^{2}$ Microbiology Division, Research Center for Biology, Indonesian Institutes of Sciences, Cibinong 16911, Indonesia
}

The community structure of sporulating fungi on decaying branch and leaf litters of Shorea spp. were studied to reveal the common saprobic fungi. The study was mainly based on morphological observation. Twenty-nine species of the sporulating fungi were found on Shorea spp. litters at Situ Gede and Bubulak forest area, Bogor, West Java. The fungi included seven species of Ascomycetes (Annulohypoxylon purpureonitens, Diatrype chlorosarca, Didymosphaeria epidermidis, Lophiostoma sp., Lophodermium sp., Pemphidium sp., and Valsa sp.) and 22 species of anamorphic taxa that consisted of 12 Coelomycetes (Coniella musaiaensis, Coryneum betulinum, Hendersoniopsis thelebola, Lasiodiplodia theobromae, Lasmeniella guaranitica, Leptodothiorella sp., Massariothea themedae, Pestalotia guepinii, Pestalotiopsis sp., Pseudolachnea hispidula, Septoriella sp., and unidentified species of Coelomycetes) and 10 Hyphomycetes (Beltraniella portoricensis, Cryptophialoidea fasciculata, Hermatomyces spaerichus, Kiliophora ubiensis, Minimidochium setosum, Monodisma fragilis, Nodulisporium sp., Stilbella fimetaria, Virgatospora echinofibrosa, and unidentified Hyphomycetes). The most common taxa occuring on decaying leaf litter were B. portoricensis and Pemphidium sp., while those on decaying branch material were $L$. theobromae and $C$. fasciculata. The fungal community was subtrate specific. The community on decaying branch litter was more diverse than that on leaf litter. The $\mathrm{C} / \mathrm{N}$ ratio of the substrate was closely related to the structure of the community.

Key words: community structure, frequency of occurrence, fungi, Shorea spp.

Struktur komunitas cendawan berspora pada serasah ranting dan daun Shorea spp. dipelajari untuk mengetahui cendawan saprob yang umum pada serasah tersebut. Penelitian dilakukan berdasarkan pada pengamatan morfologi. Sebanyak 29 spesies cendawan berspora ditemukan pada serasah Shorea spp. yang dikoleksi dari areal hutan yang terletak di Situ Gede dan Bubulak, Bogor. Jawa Barat. Cendawan terdiri dari 7 spesies askomiset (Annulohypoxylon purpureonitens, Diatrype chlorosarca, Didymosphaeria epidermidis, Lophiostoma sp., Lophodermium sp., Pemphidium sp., dan Valsa sp.) dan 22 spesies cendawan anamorfik yang terdiri dari 12 soelomiset (Coniella musaiaensis, Coryneum betulinum, Hendersoniopsis thelebola, Lasiodiplodia theobromae, Lasmeniella guaranitica, Leptodothiorella sp., Massariothea themedae, Pestalotia guepinii, Pestalotiopsis sp., Pseudolachnea hispidula, Septoriella sp., dan soelomiset yang tidak teridentifikasi) dan 10 hifomiset (Beltraniella portoricensis, Cryptophialoidea fasciculata, Hermatomyces spaerichus, Kiliophora ubiensis, Minimidochium setosum, Monodisma fragilis, Nodulisporium sp., Stilbella fimetaria, Virgatospora echinofibrosa, dan hifomiset yang tidak teridentifikasi). Spesies cendawan yang umum ditemukan pada serasah daun adalah B. portoricensis dan Pemphidium sp., sedangkan pada serasah ranting adalah $L$. theobromae dan C. fasciculata. Komunitas cendawan bersifat spesifik substrat. Komunitas cendawan pada serasah ranting lebih beragam dibandingkan pada serasah daun. Rasio $\mathrm{C} / \mathrm{N}$ pada substrat mempengaruhi struktur komunitas cendawan tersebut.

Kata kunci: cendawan, frekuensi keberadaan, Shorea spp, struktur komunitas

Shorea spp.(Dipterocarpaceae) dominantly inhabit rainforests in Southeast Asia, especially in Malaysia and Indonesia. In Indonesia, these trees spread across the island of Sumatra, Bangka-Belitung, Kalimantan and several locations in Java island (The Ministry of Forestry 2007). In natural ecosystems, Shorea spp. posses an important role in maintaining the balance of the ecosystem because they produce abundant lignocellulosic rich substrates as a source of nutrients for the survival of microorganisms including saprobic

*Corresponding author; Phone/Fax: 021-8765066/0218765062, Email: imanhidayat@yahoo.com fungi. The saprobic fungi are known as the major wood and leaf decomposing organisms which play an important role in the nutrient cycle of forest areas including Shorea spp. plantations. During the decomposition process, the saprobic fungi degrade lignocellulosic materials into more simple compounds (Osono 2007).

Hyde and Taylor (2003) noted that there are many benefits from studying the diversity of saprobic fungi. These include novel agents with important medicinal properties (Yang et al. 2011), and for other bioactive compounds (Strobel 2003), and discoveries of new 
taxa (genera and species). Ho et al. (2001) found ten new species and a new genus during their study on the saprobic fungi on submerged wood from streams. In addition, numerous new species have been discovered from palms (Goh and Hyde 1996; Yanna et al. 1997; 1998; Hidayat et al. 2006).

There are many fungal community studies on plants that have been reported worldwide. However, a study based on the fungal community structure of decaying litter of Shorea spp. has not widely been reported. Few studies were reported from Thailand (Osono et al. 2009) and India (Soni et al. 2011), and so far none from Indonesia. Therefore, research on the fungal community of Shorea spp. was undertaken in order to provide information regarding the fungal community inhabiting Shorea spp. litter.

\section{MATERIALS AND METHODS}

Collection of Samples. Samples of Shorea spp. litter were collected from Shorea plantation research area managed by the research and development centre for forest conservation and rehabilitation, located at the Situ Gede village and Bubulak village, Bogor, West Java. Samples were taken from 13 sampling sites which were designed plots $(50 \mathrm{~m} \times 50 \mathrm{~m})$. The distance between each sampling site is $3 \mathrm{~m}$. In total, 260 samples of Shorea spp. (130 branch and 130 leaf samples) were collected. The size of each branch is $10 \mathrm{~cm}$ lengths, regardless the diameter. Samples were placed in resealed plastic bags. After sealing, each bag was labeled as follows: name of the sample, collecting site, collector, and collection date. The environment parameters such as $\mathrm{pH}$, light intensity, soil water content, water content of branch and leaf litter, the $\mathrm{C} / \mathrm{N}$ ratio of branch and leaf litter were also measured.

Examination of Materials. On returning to the laboratory, the materials were immediately incubated and examined periodically over one month. The materials were examined for saprobic Ascomycetes, Coelomycetes, and Hyphomycetes. The materials were examined using an Olympus SZX7 dissecting microscope to determine the presence of the fungal fruiting structures, and an Olympus CX41 to determine microscopic structures.

For ascomycetes and coelomycetes, a sharp one sided razor blade or a pair of Inox 5 fine forceps were used to carefully remove the top of the fruiting body. The specimens were rehydrated if the contents were dry or crystalline by using distilled water or potassium hydroxide $(\mathrm{KOH}) 3 \% \mathrm{w} / \mathrm{v}$ before extraction. The contents were placed in a drop of distilled water on a slide and covered with an 18 x $18 \mathrm{~mm}$ coverslip. Hyphomycetes examination was prepared by using a pair of Inox 5 fine forceps. Water was used for all examinations, spore/conidia measurements, and most of the photographs/line drawings. Shear's solution was added to the slides for permanent fixation. The slides were heated to remove air bubbles in the Shear's solution and the edges of the coverslip sealed with two layers of clear nail varnish. The slides were labeled with the number of each specimen.

Detailed observations of morphological characters were carried out by means of an Olympus CX41 light microscope using an oil immersion lens (1000×). Single spore isolation of each new fungus encountered was as reported by Choi et al. (1999) with modification.

Identification Procedures. The following texts were consulted for basic identification such as Hyde et al. (2000) and Hyde and Taylor (2003) for Ascomycetes; Nag Raj (1993) and Sutton (1980) for Coelomycetes; and Ellis (1971, 1976), Carmichael et al. (1980) and Seifert et al. (2011) for Hyphomycetes. Further identification of fungal specimens was by reference to the recent publications in various journals of mycology. The following fungal database websites were also used such as Index Fungorum (), Mycobank (http://www. mycobank.org) and USDA fungus-host database (http://nt.ars-grin.gov/fungaldatabases/fungus host/fungushost.cfm.

Data Analysis. Frequency of occurence (FO) of a taxon was calculated according to the following formula:

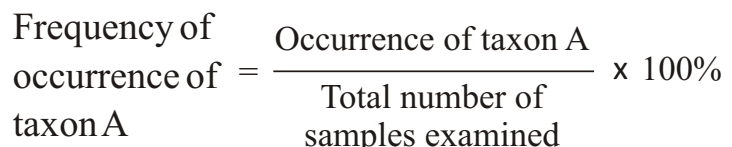

The total number of species and the number of fungi per sample were recorded and calculated. Based on the percentage occurrence of different species, grouping was done as follows: very frequent $(>10 \%)$, frequent $(>5 \%-10 \%)$, less frequent $>1 \%<5 \%)$, and rare $(<1 \%)$.

Shannon-Wiener diversity $\left(\mathrm{H}^{\prime}\right)$ and evenness indices (E) were calculated for each sampling point along with Margalef's species richness. Calculations were carried out according to Magurran (1988). The Margallef index on diversity $\left(\mathrm{D}_{\mathrm{Mg}}\right)$ was calculated as follows:

Margallef index $\mathrm{D}_{\mathrm{Mg}}=(\mathrm{S}-1) / \mathrm{lnN}$; $\mathrm{D}_{\mathrm{mg}}=$ Margalef Index 


$$
\begin{aligned}
& \mathrm{S}=\text { the number of species } \\
& \mathrm{N}=\text { the total number of fungal } \\
& \text { occurrences } \\
& \text { Shannon index }\left(\mathrm{H}^{\prime}\right)=-\sum_{i=1}^{n} p i \cdot \ln p i \\
& \begin{aligned}
\mathrm{pi}= & \text { the proportional abundance of } \\
& \text { the } \mathrm{i}^{\text {th }} \text { species }=(\mathrm{ni} / \mathrm{N})
\end{aligned}
\end{aligned}
$$

The relationship between assemblage of the fungal community and different organ type of Shorea spp. was also analysed using a simple correspondence analysis (CA). The analysis were performed using Minitab 15 software.

\section{RESULTS}

Community Structure of Sporulating Fungi on Decaying Litters of Shorea spp. Examination of decaying branch and leaflitter of Shorea spp., indicated that only $50 \%$ of the litter containing fungi. In those litter, 29 of the sporulating fungal taxa, comprising seven species of Ascomycetes (representing 24.1\% of all taxa), and 22 species of anamorphic fungi (representing $75.9 \%$ of all taxa) were found. The anamorphic fungi were composed of 12 Coelomycetes (41.4\%) and 10 Hyphomycetes (34.5\%) (Fig 1).

The number of fungal taxa found on decaying branch litter was higher than those on leaf litter (Table 1). Twenty-two species of fungi were recorded for the branch litter, and seven species were found in the leaf litter. Beltraniella portoricensis and Pemphidium sp. appeared to be the most common taxa inhabiting leaf litter with FO of 16.9 and $11.5 \%$ respectively (Table 1). During the process of decaying branch litter, Lasiodiplodia theobromae and Cryptophialoidea fasciculata were determined to be the most frequent fungi found during this study. The remaining fungi were found either less frequently or were rare based on their FO on branch or leaf litter (Table 1).

Based on fungal groups, Coelomycetes appeared as the most dominant group found on decaying branch litter with 11 species (total abundance 36), followed by Hyphomycetes with 6 species (total abundance 28), and Ascomycetes with 5 species (13 total abundance) (Fig 2, Fig 3). In the case of leaf litter, Hyphomycetes were found to be the highest fungal group in species richness and abundance, with 4 species and score of 55, respectively. Ascomycetes appeared as the second highest in species richness with 2 taxa recorded and score of 32, followed by Coelomycetes taxa with 1 species and score of 1 (Fig 2, Fig 3).

The Shannon-Wiener index was measured on thirteen sites in the sampling location (Fig 4). The diversity of sporulating fungi on branch litter was higher than those on leaf litter. This data was also supported by the Margalef index calculation (Table 1). Evenness was higher on the branch litter than on the leaf litter (Table 1). This means that every fungal species in branch litter has a higher frequency of occurrence than for leaflitter.

Correspondence Analysis (CA) of the fungal community on branch and leaf litter showed that taxa such as Annulohypoxylon purpureonitens, Diatrype chlorosarca, Didymosphaeria epidermidis, Lophiostoma sp., Valsa sp., Coniella musaiaensis, Coryneum betulinum, Hendersoniopsis thelebola, Lasiodiplodia theobromae, Lasmeniella guaranitica, Leptodothiorella sp., Massariothea themedae, Pestalotia guepinii, Pseudolachnea hispidula, Septoriella sp., Cryptophialoidea fasciculata, Hermatomyces spaerichus, Minimidochium setosum, Monodisma fragilis, Nodulisporium sp., Virgatospora echinofibrosa, and Coelomycetes sp.1 were common on branch litter. However, on leaf litter, taxa such as Lophodermium sp., Pemphidium sp., Pestalotiopsis sp., Beltraniella portoricensis., Kiliophora ubiensis, Stilbella fimetaria, and Hyphomycetes sp. 1 were more common (Fig 5).

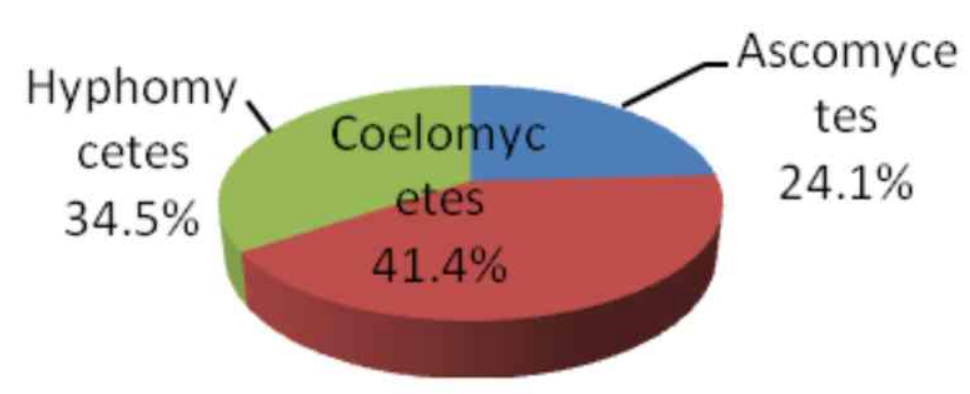

Fig 1 Comparison of fungal community on Shorea spp. based on number of species. 
Table 1 Frequency of occurence (FO) of sporulating fungi on branch and leaf litter of Shorea spp.

\begin{tabular}{lcccc}
\hline Taxa & Branch & Leaf & Total & FO (\%) \\
\hline Ascomycetes & & & & \\
Annulohypoxylon purpureonitens (Aap) & 2 & 0 & 2 & 0.7 \\
Diatrype chlorosarca (Adc) & 5 & 0 & 5 & 1.9 \\
Didymosphaeria epidermidis (Ade) & 3 & 0 & 3 & 1.1 \\
Lophiostoma sp. (Als) & 2 & 0 & 2 & 0.7 \\
Lophodermium sp. (Ald) & 0 & 2 & 2 & 0.7 \\
Pemphidium sp.(Apd) & 0 & 30 & 30 & 11.5 \\
Valsa sp.(Avs) & 1 & 0 & 1 & 0.3
\end{tabular}

Anamorphic fungi

Coelomycetes

Coniella musaiaensis $(\mathrm{Ccm})$

$\begin{array}{rrrr}3 & 0 & 3 & 1.1 \\ 1 & 0 & 1 & 0.3 \\ 1 & 0 & 1 & 0.3 \\ 17 & 0 & 17 & 6.5 \\ 1 & 0 & 1 & 0.3 \\ 1 & 0 & 1 & 0.3 \\ 2 & 0 & 2 & 0.7 \\ 2 & 0 & 2 & 0.7 \\ 0 & 1 & 1 & 0.3 \\ 1 & 0 & 1 & 0.3 \\ 6 & 0 & 6 & 2.3 \\ 1 & 0 & 1 & 0.3\end{array}$

Hyphomycetes

Beltraniella portoricensis (Hbp)

*FO $=$ Frequency of occurence

\section{DISCUSSION}

The present study is one amongst a few fungal community studies on branch and leaf litter of Shorea spp., and it is the first study in Indonesia. Osono et al. (2009) and Soni et al. (2011) studied the fungal community on leaf litter only. Several studies of fungal community on other host plants, such as palmae, bamboo, mangrove, etc. have been carried out in several areas of the tropics (Huhndorf and Lodge 1997; Hyde and Alias 2000; Hyde and Sarma 2001; Maria and Sridhar 2003; Hyde and Taylor 2003; Karamachand et al.2009).

The current study shows that species diversity $\left(\mathrm{H}^{\prime}\right)$ and species richness $\left(\mathrm{D}_{\mathrm{Mg}}\right)$ of the fungal community on the branch litter was higher than for leaf litter (Table 1). The higher the $\mathrm{C} / \mathrm{N}$ ratio and density of wood, rather than that of leaves best supported the growth of fungi on the wood (Kodsueb et al. 2008). On palm, Pinnoi et al. (2006) suspected that thicker cell walls may yield more nutrients, in particular cellulose and starch. These nutrients could sustain the growth most of the fungi. They found that the palmicolous fungi were more prevalent on palm petioles $(53 \%)$ than on rachides 


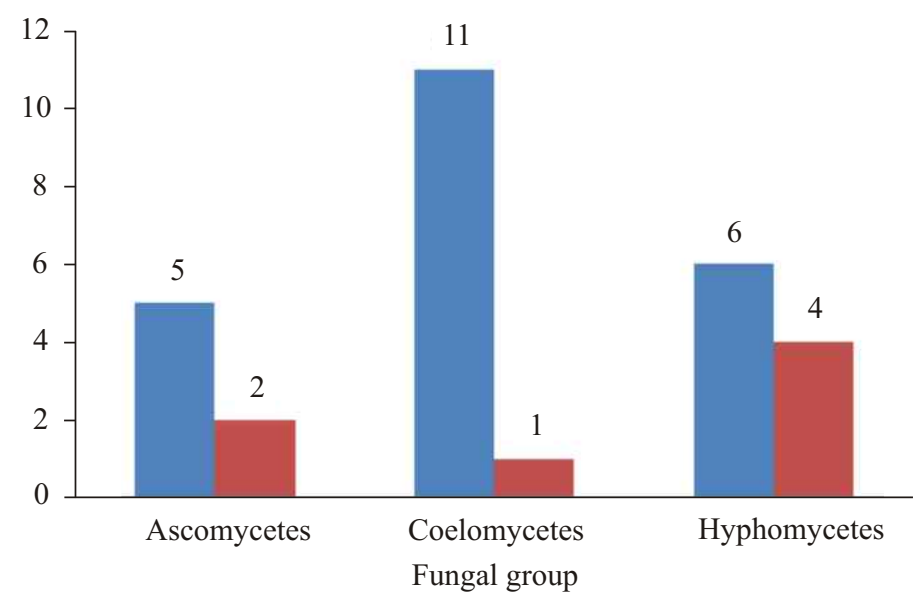

Fig 2 Distribution of all taxa recorded from of Shorea spp. The graphics are presented based on qualitative data of species richness. $\square$ :branch litter; $\square$ :leaf litter.

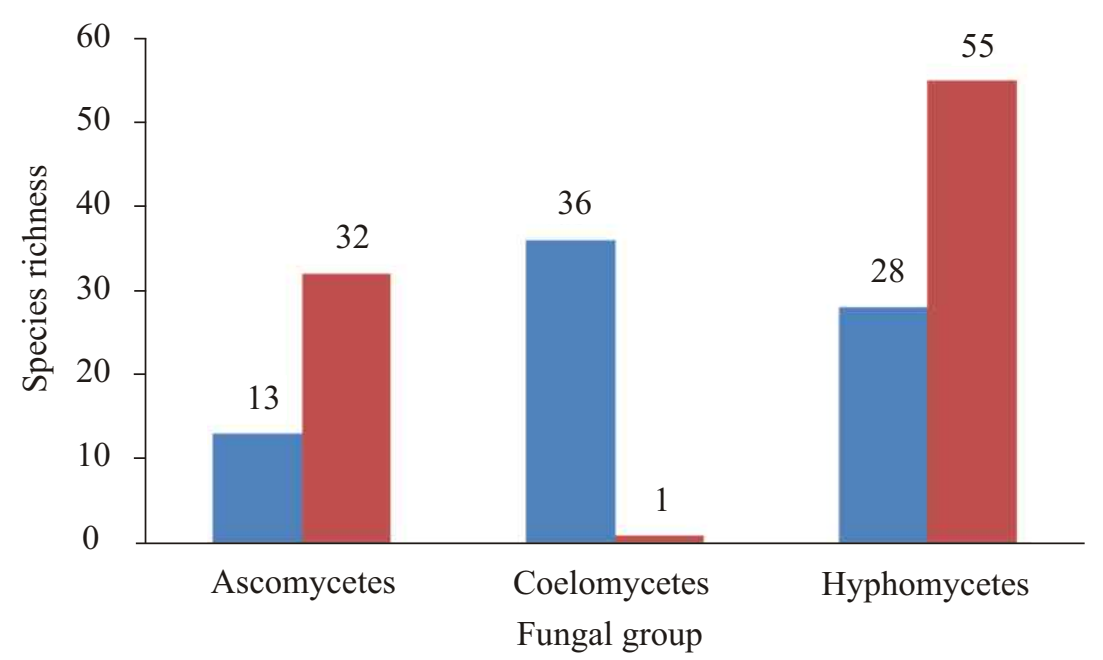

Fig 3 Distribution of all taxa recorded from of Shorea spp. The graphics are presented based on quantitative data (total abundance). $\square$ : branch litter; $\square$ : leaflitter.

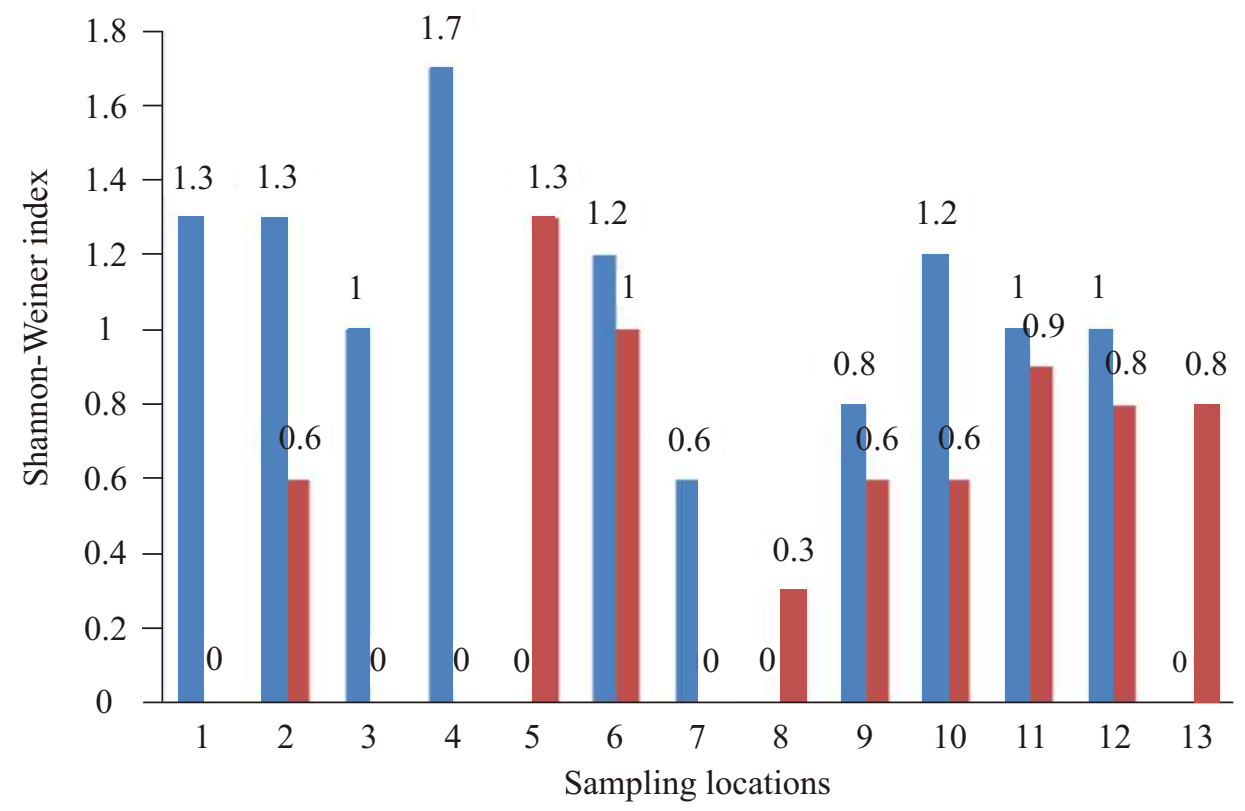

Fig 4 Histogram of Shannon-Wiener diversity index (H') showing the diversity of the fungal community on thirteen sites in the sampling location. $\square$ : branch litter; $\square$ : leaflitter. 


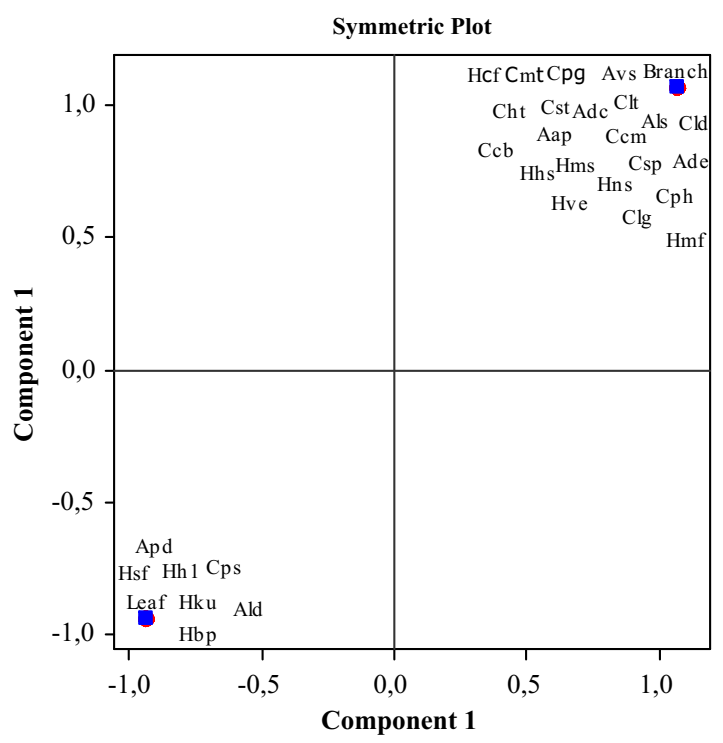

Fig 5 Correspondence analysis of fungal community on branch and leaf litter. Taxa are shown by their acronym.

(30\%) and leaves (17\%). Hyde and Sarma (2006) noted that branch thickness may also offer a better substrate for fungal colonization than that of leaves which were thinner. Leaves contain mainly parenchymatous cells which are thin-walled, with chloroplasts and rich in starch, while rachides and petioles have more sclerenchyma associated with their vascular bundles.

Our analyses of fungal community structure, based on the artificial taxonomical groups, showed that anamorphic fungi were more dominant than teleomorphic fungi, and this result is in agreement with previous studies carried out by Osono et al. (2009) and Soni et al. (2011). Osono et al. (2009) noted that hyphomycetes fungi were commonly found at the early stage of fungal community succession. However, the reasons for the higher dominance of anamorphic fungi over Ascomycetes (teleomorphic fungi) are unknown.

Several fungal species commonly found on decayed litter of Shorea spp. by Osono et al. (2009) and Soni et al. (2011), such as Beltraniella, Pestalotiopsis, and Lophodermium were also found in the current study. Shirouzu et al. (2009) noted that Beltraniella species most commonly occured on newly fallen leaves and their FO usually decreased with decay. The distributions of the fungal community on branch and leaf litter were different (Fig 5). It is apparent that several taxa only occured either on branch or leaf littter. Distinct fungal community composition occurs on different organs of Shorea spp. is indicated by the fact that fungi on Shorea litter are substrate specific. There is limited information regarding the physical structure of each organ of Shorea spp., therefore, it is difficult to determine the factors affecting the distinct community of each organ type.

On the contrary, the FO of fungi in leaf litter was higher than that of branch litter. This probably relates to water content of substrates. The water content of leaf litter of Shorea spp. was higher than that of branch litter (Table 2). Water has been recognized as an important factor in fungal growth, in particular during the germination process and the dispersal of fungal propagules. The water content is directly related to a high relative humidity required for spore germination, growth, and reproduction of fungi (Yoder and Wood 1973). Fungi are well-recognized as organisms that utilized sugar due to sugar occupying a central position in fungal metabolism. Hyde and Sarma (2001) noted that other parameters to be considered as the factors affecting the frequency of occurrence of the fungal community on different habitats included $\mathrm{pH}$, incubation time, ecological niches, availability of the substrate, quality of the substrate (old or young samples/ soft or hard tissue), nutrient availability, DOD, COD, and BOD, seasonality and succession, temperature (tropical or subtropical), and host specificity/main host samples.

Different fungal communities occured on branch and leaf litters of Shorea spp. indicating that substrates might play an important role in determining species composition by selectively stimulating or inhibiting the growth of specific fungi. Different parts of the Shorea spp. (i.e. leaf and branch) were found to support different fungi, pointing to the existence of a distinct ecological niche. This indicated that some fungi may preferentially develop on certain tissue types, as previously reported by Hyde and Alias (2000). 
Table 2 Environmental parameters in samples location

\begin{tabular}{lc}
\hline Parameters & Value \\
\hline pH of soil & 6 \\
Light intensity & 120 \\
Water content of soil & $38.34 \%$ \\
Water content of & \\
$\quad$ branch litter & $3.39 \%$ \\
leaf litter & $3.98 \%$ \\
branch litter & \\
$\quad$ leaf litter & 67.12 \\
\hline
\end{tabular}

In relation to the fungal community on decayed plant substratum, the nature of the host substratum (chemical), minor components of the substratum, lignin/cellulose ratio, and nitrogen/carbohydrate ratio probably play important roles as selective factors determining which group of fungi colonize the substrate at different stages of decomposition. Host plants may contain low to high amounts of compounds that are toxic or inhibit the growth of fungi e.g. phenols, while wood density of a substratum may also influence the ability of fungi to colonize (Pinruan et al. 2007). Based on phytochemical studies of Shorea spp., the main secondary metabolites of this plant genus is a class of phenolic compounds, such as oligostilbenoid, flavonoids, phenyl propanoid, and phenolic acid derivates. Rohaiza et al. (2011) have been isolated four oligostilbenes of (-)-e-viniferin, (-)-ampelopsin E, (-)hopeaphenol and shoreaphenol from the acetone extract of S. hopeifolia. Oligostilbene compounds exhibit a variety of significant bioactivities, including anti-bacterial (Nitta et al. 2002) and anti-fungal (Kusuma and Tachibana 2007). Stilbene derivates are known to be abundantly distributed in the plants belonging to the Dipterocarpaceae, Vitaceae, Leguminosae, and Cyperaceae (Ohguchi et al. 2003). Therefore, the smaller number of sporulating fungi in this study, as compared to studies on another hosts such as bamboo (Cai et al.2006), palm (Pinruan et al.2007), mangrove plants (Maria and Sridhar 2003), were probably due to the phenolic compound contents in the Shorea plants which inhibited fungal growth and thus protected plant tissues (including leaf and branch material) from the fungal colonization.
In conclusion, there were different fungal community structures which occupied decaying branch and leaf litters of Shorea spp. However, the factors that influenced the distinct fungal communities structures on branch and leaf litters were difficult to determine. Therefore, future studies should take into consideration all factors effecting the frequency of occurence of fungi in Shorea spp., in particular from the hosts point of view.

\section{REFERENCES}

Cai L, Ji KF, Hyde KD. 2006. Variation between freshwater and terrestrial fungal communities on decaying bamboo culms. Antonie van Leeuwenhoek 89(2):293301. doi:10.1007/s10482-005-9030-1.

Carmichael JW, Kendrick WB, Conners LL, Sigler L. 1980. Genera of Hyphomycetes. Edmonton: The University of Alberta Press.

Choi YW, Hyde KD, Ho WWH. 1999. Single spore isolation of fungi. Fungal Divers. 3:29-38.

Ellis MB. 1971. Dematiaceous Hyphomycetes. Kew, Surrey: CAB International.

Ellis MB. 1976. More Dematiaceous Hyphomycetes. Kew, Surrey: CAB International.

Goh TK, Hyde KD. 1996. A new species of Nectria from Mauritia flexuosa (Arecaceae) in Ecuador and a key to Nectria and allied genera on palms. Mycoscience. 37(3):277-282. doi:10.1007/BF02461298.

Hidayat I, Jeewon R, To-anun C, Hyde KD. 2006. The genus Oxydothis: new palmicolous taxa and phylogenetic relationships within the Xylariales. Fungal Divers. 23:159-179.

Ho WH, Hyde KD, Hodgkiss IJ, Yanna. 2001. Fungal communities on submerged wood from streams in Brunai, Hong Kong, and Malaysia. Mycoln Res. 
105(12):1492-1501. doi:10.1017/S095375620100507X.

Huhndorf SM, Lodge DJ. 1997. Host specificity among wood-inhabiting pyrenomycetes (fungi, ascomycetes) in a wet tropical forest in Puerto Rico. Tropical Ecology. 38:307-315.

Hyde KD, Alias SA. 2000. Biodiversity and distribution of fungi associated with decomposing Nypa fruticans. Biodiversity and Conservation. 9(3):393-402. doi:10.102 3/A:1008911121774.

Hyde KD, Taylor JE, Fröhlich J. 2000. Genera of ascomycetes from palm. Hong Kong: Fungal Diversity Press.

Hyde KD, Sarma VV. 2001. A review on frequently occurring fungi in mangroves. Fungal Divers. 8:1-34.

Hyde KD, Sarma VV. 2006. Biodiversity and ecological observations on filamentous fungi of mangrove palm Nypa fruticans Wurumb (Liliopsida-Arecales) along the Tutong River, Brunei. Indian J Mar Sci. 35(4):297307.

Hyde KD, Taylor JE. 2003. Microfungi of tropical and temperate palms. Hong Kong: Fungal Diversity Press.

Karamachand KS, Sridhar KR, Bhat R. 2009. Diversity of fungi associated with estuarine sedge Cyperus malaccensis Lam. J of Agricultural Technology. 5:111127.

Kodsueb R, EHC McKenzie, Lumyong S, Hyde KD. 2008. Fungal succession on woody litter of Magnolia liliifera (Magnoliaceae). Fungal Divers. 30:55-72.

Kusuma IW, Tachibana S. 2007. Antifungal compounds isolated from tropical and temperate woods [Abstract]. In: ACS Symposium Series. 954 (Materials, Chemicals, and Energy from Forest Biomass):377-390.

Magurran AE. 1988. Ecological Diversity and Its Measurement. London Sydney: Croom Helm. p 11-37. doi:10.1007/978-94-015-7358-0.

Maria GL, Sridhar KR. 2003. Diversity of filamentous fungi on woody litter of five mangrove plant species from the southwest coast of india. Fungal Divers. 14:109-126.

Nag Raj TR. 1993. Coelomycetous Anamorphs with Appendage-Bearing Conidia. Waterloo: Mycologue Publications.

Nitta T, Arai T, Takamatsu H, Inatomi Y, Murata H, Iinuma M, Tanaka T, Ito T, Asai F, Watabe K. 2002. Antibacterial activity of extracts prepared from tropical and subtropical plants on methicillin-resistant Staphylococcus aureus. J Health Sci. 48(3):273-276. doi:10.1248/jhs.48.273.

Ohguchi K, Tanaka T, Ito T, Iinuma M, Matsumoto K, Akao Y, Nozawa Y. 2003. Inhibitory effects of resveratrol derivatives from Dipterocarpaceae plants on tyrosinase. Biosci Biotechnol Biochem. 67(7):1587-1589. doi:10.1271/bbb.67.1587.
Osono T. 2007. Ecology of ligninolytic fungi associated with leaf litter decomposition. Ecol Res. 22(6):955-974. doi:10.1007/s11284-007-0390-z.

Osono T, Ishii Y, Takeda H, Seramethakun T, Khamyong S, To-Anun C, Hirose D, Tokumasu S, Kakishima M. 2009. Fungal succession and lignin decomposition on Shorea obtusa leaves in a tropical seasonal forest in northern Thailand. Fungal Divers. 36:101-119.

Pinnoi A, Lumyong S, Hyde KD, Jones EBG. 2006. Biodiversity of fungi on the palm Eleiodoxa conferta in Sirindhorn peat swamp forest, Narathiwat, Thailand. Fungal Divers. 22:205-218.

Pinruan U, Hyde KD, Lumyong S, McKenzie EHC, Jones EBG. 2007. Occurence of fungi on tissue of the peat swamp palm Licuala longicalycata. Fungal Divers. 25:157-173

Rohaiza S, Yacoob WA, Din LB, Nazlina I. 2011. Cytotoxic oligostilbenes from Shorea hopeifolia. Afr J Pharm. Pharmacol. 5(10):1272-1277.

Seifert K, Jones GM, Gams W, Kendrick B. 2011. The Genera of Hyphomycetes. Utrecht: CBS-KNAW Fungal Biodiversity Centre.

Shirouzu T, Hirose D, Fukasawa Y, Tokumasu S. 2009. Fungal succession associated with the decay of leaves of an evergreen oak, Quercus myrsinaefolia. Fungal Divers. 34:87-109.

Soni KK, Pyasi A, Verma RK. 2011. Litter decomposing fungi in sal (Shorea robusta) forests of central India. Nusantara Bioscience 3:136-144.

Strobel GA. 2003. Endophytes as sources of bioactive products. Microbes and Infection 5(6):535-544. doi:10. 1016/S1286-4579(03)00073-X.

Sutton BC. 1980. The Coelomycetes: Fungi Imperfecti with Pycnidia, Acervuli, and Stromata. Kew, Surrey: Commonwealth Mycological Institute.

The Ministry of Forestry. 2007. Departemen kehutanan bangun sumber benih dan kebun benih meranti. www.dephut.go.id [11 Mar 2012].

Yang XL, Zhang S, Zhu HJ, Luo DQ. 2011. Dihydroberklasmin A: Anew Eremophilane sesquiterpenoid from the fermentation broth of the plant endophytic fungus Pestalotiopsis photiniae. Molecules 16(2):1910-1916. doi:10.3390/molecules16021910.

Yanna, Hyde KD, Fröhlich J. 1997. A new species of Appendicosopora from Hong Kong. Mycoscience 38(4):395-397. doi:10.1007/BF02461678.

Yanna, Hyde KD, Goh TK. 1998. Koorchaloma novojornalis sp. nov., a new sporodochial fungus from Hong Kong. Fungal Divers. 1:193-197.

Yoder DL, Wood JLL. 1973. Fungal spore germination on natural and steril soil. J Gen Microbiol. 74(1):107-117. doi:10.1099/00221287-74-1-107. 